\title{
Debt in a Business and Islamic Perspective
}

\author{
Fianita Malati *, M Andri Radiany **, Wulandari Harjanti ${ }^{* *}$, Ali Farhan**, Etin Puspitasari ** \\ Sekolah Tinggi Ilmu Ekonomi Mahardhika, Surabaya, Indonesia \\ DOI: 10.29322/IJSRP.11.10.2021.p11805 \\ http://dx.doi.org/10.29322/IJSRP.11.10.2021.p11805
}

\begin{abstract}
This research is motivated by a contradiction between the need for corporate financing and interest costs which are prohibited by Islam. By raising two different perspectives in viewing debt, which are business and Islam, hopefully those point of views of how a Muslim manager mentions debt and his business needs. By using the literature review method, the conclusion is that in the business perspective, debt is a means of leveraging performance as well as principal to the agent. Meanwhile, in the Islamic perspective, debt is a social contract that is not given the consent to take profit (usury / interest), but there are other business contract alternatives that are not in the scheme called 'debt', namely; murabahah, salam, and mudaraba.
\end{abstract}

Index Terms- debt, cost of capital, Islamic financial management, business

\section{INTRODUCTION}

A s quoted by Brigham and Gapenski (2006), which states that the main goal of the corporation is to increase corporate value by increasing the prosperity of shareholders or shareholders. In order for this achievement to be achieved, a manager is given mandate responsibility for the corporation. These professionals or managers will be responsible for budget allocations either from within the company or from outside the company. Professionals appointed by shareholders are expected to act on behalf of shareholders. High corporate value is the main goal of corporate owners, because a high personal value represents the prosperity of shareholders.

Fama (1978) argues that the value of a corporation will offer the price of its stock market. The company has a goal to maximize the value of its shares in the market (Karnadi, 1993). The prosperity of shareholders will increase as the value of the company increases to a high level of shareholder investment. Stock value that represents the company's high value. This can be illustrated simply as follows: firm value (value) is debt (debt) plus equity (equity). The increase in capital alone will increase the price per share of the company (Atmaja, 2008). The increase in the value of capital itself can be achieved through the accumulation of profits, which managerial affects the alternative capital structure chosen to achieve the most cost efficient.

Capital structure is a permanent corporate's financing, especially long-term liabilities (Obligation), the capital structure of a company can be calculated by calculating the ratio of total liabilities to total equity (debt to equity ratio) (Anshari, 2009). The tradeoff theory presented by Fama (1978) Managers can make decisions regarding the debt ratio to maximize the value of the company to be issued at its share price. Jensen (2001) states that if you want to maximize company value, it is not only the equity value that must be considered, but also all sources of capital financing such as debt, warrants, or preferred stock.

In line with Jensen (2001), Fama and French (1998) argue that a financial decision taken (related to sources of capital financing) will affect other financial decisions and have an impact on firm value. Meanwhile (Helfert, 1997) argues that the market value of the company is not just equity, but the market value of the company's equity is added by the market value of the debt owned by the company. Thus, increasing the amount of debt can also be a company assessment (Anshari, 2009). Compensation for debt in mainstream business is the cost of interest, which in the Islamic context, interest on debt is prohibited, otherwise the cost of capital arises from activities such as investment (profit-loss sharing). Perhaps considering interest costs with relevant investment costs if the business perspective is not based on Islamic teachings, but things are different if a business makes Islam the fundamental principle of business management, financial management decisions based on debt become a dilemma, because the business risk is normative-ethical, not material. However, on the other hand, the pressure on management to increase the company's value is enormous, with debt as an alternative to its capital structure. Therefore, the following article will further discuss how debt is a source of business financing from a conventional and Islamic perspective?

\section{LITERATURE REVIEW}

Agency Theory

This publication is licensed under Creative Commons Attribution CC BY.

http://dx.doi.org/10.29322/IJSRP.11.10.2021.p11805

WWW.ijsrp.org 
In every flow of economic information there is an issue regarding agency, this is explained further by Jensen (1983) that agency theory develops into two parts, namely positivist and principal-agent. Both have the same unit of analysis, namely the contract between the principal and the agent. It also has the same assumptions about people, organizations and information. However, they differ in mathematical rigor, dependent variable, and style.

The theory of resistance tries to disentangle the most efficient contract to regulate principal - agent relationships on the basis of human behavior assumptions such as self-interest, limits of rationality, risk ad version, conflict within organizations, and information as a commodity that can be purchased (Alchian, and Demsetz, 1972). Next, this principal-agent contract will raise a question, which contract is more efficient for the company, is it a behavior-oriented contract such as salary or results-oriented contracts such as commission, stock options, transfer of property rights? As a result of the stimulus to the agent, this contract will give different results in terms of efficiency. This is because humans will have different rationalities and utilities when they achieve a goal. Agency structure can be implemented in many types of regulations, ranging from problems at the macro level, such as management policies, to the micro level such as human error, unprofessional management behavior. Agency theory can be implemented in the operations of an organization such as compensation, acquisition and diversification strategies, board of directors' relationships, ownership structures, financing, and innovation (Ang et al., 2000; Barnea et al., 1985; Bergen et al., 1992).

Researchers in the fields of accounting, economics, finance, marketing, political science, organizational behavior, and sociology have used agency theory in discussing social issues in organizations (Demski, and Feltham, 1978; Spence, and Zeckhauser, 1971; Fama, 1980; Basu et al., 1985; Mitnick, 1986; Eisenhard, 1985, 1988; White, 1985). When the contract between the principal and the indicator agent is the outcome, the agent will tend to behave in accordance with the principal's interests, and the information system can also prevent the agent from being opportunistic. Because effective information systems provide information for principals what agents are working on, as Fama (1980) and Fama and Jensen (1983) argue, explaining the effect of capital market information and efficient labor on managerial opportunism.

\section{Capital Structure}

\section{Trade Off Theory}

Myers (2001) revealed his opinion regarding the trade-off theory, that the company will decide to finance through debt to a certain level, where the tax savings (tax shields) from additional debt are equal to the cost of financial distress. The cost of financial distress is the cost of bankruptcy (bankruptcy costs) or reorganization, and agency costs that increase as a result of a decline in the credibility of a company. Trade-off theory in determining the optimal capital structure incorporates several factors, including taxes, agency costs and financial distress costs, but still maintains assumptions of market efficiency and asymmetric information as a balance and benefits of using debt. The optimal level of debt is achieved when the tax savings reach their maximum against the cost of financial hardship.

\section{Pecking Order Theory}

According to Myers (1984) the pecking order theory states that "Companies with high levels of profitability have low levels of debt, because companies with high profitability have abundant internal sources of funds." In this theory there is no optimal capital structure. Specifically, companies have a preference order in the use of funds. According to pecking order theory, there is a hierarchical scenario in choosing funding sources, namely:

a. Companies prefer to use internal funding sources or internal funding rather than external funding. The internal funds are obtained from retained earnings resulting from the company's operational activities.

b. If external funding is required, the company will first choose from the safest securities, namely debt with the lowest risk, down to riskier debt, hybrid securities such as convertible bonds, preferred stock, and finally common stock.

c. There is a constant dividend policy, that is, the company will set a constant dividend payment amount, regardless of how much the company gains or loses.

d. To anticipate a shortage of cash stock due to a constant dividend policy and fluctuations in the rate of profit, as well as investment opportunities, the company will take an investment portfolio that is currently available. Pecking order theory does not indicate a capital structure target. Pecking order theory explains sequences of funding. Financial managers do not take into account the optimal level of debt. Fund requirements are determined by investment needs. This pecking order theory can explain why companies that have high levels of profit actually have low levels of debt. In reality, there are companies that use funds for their investment needs not according to the hierarchical scenario mentioned in this theory. Research conducted by Singh and Hamid (1992) and Singh (1995) states that "Companies in developing countries prefer to issue equity rather than debt in financing their companies." 


\section{RESEARCH METHODOLOGY}

The methodology used in this study uses a qualitative approach with a literature review approach to compare Islamic and business perspectives in making decisions for debt, while the data used is secondary data in the form of data from previous research results. The purpose of literature review is to get a solid theoretical basis that can provide a solution to the problem being researched, apart from that literature review can provide an overview of what other people have done before (Cahyadi, 2014). Literature reviews contain descriptions of theories, findings and other research materials obtained from reference materials to serve as the basis for research activities (Hasibuan, 2007).

\section{DISCUSSION}

\section{A. Debt in a Business View}

For a company, debt is an alternative financing that supports the company's finances, in addition to other capital options, such as preferred stock or warrants. The goal of debt policy is of course to maximize shareholder prosperity through the most efficient financial policy. Several indicators that make debt an option for corporate capital include; profitability, managerial ownership, company scale and capacity.

\section{Profitability}

Companies with insignificant profitability use debt to finance operations, but companies at a superior level of profitability choose to reduce the use of debt (Ismiyanti and Hanafi 2003). This is because the company is assumed to allocate most of the profits to retained earnings, so it relies on internal sources of funds and uses low levels of debt, however, when profits decline, the company tends to use debt as a mechanism for the transfer of wealth between creditors and principals (Ismiyanti and Hanafi 2003).

Ismiyanti and Hanafi (2003) found that profitability has a relationship to debt. The results of this study are consistent with the results of research by Myers and Majluf (1984) who also found a relationship between profitability and debt policy (debt). However, Sugiarto and Budhijono (2007) in their research found that profitability has a different effect on corporate debt. They found that the lower the profitability, the company tends to try to find additional funds so as not to fall into financial distress. Seteven \& Lina (2011), Hardiningsih and Oktaviani (2012) state that profitability has a significant effect on debt policy. The results show that debt policy has relevance to pecking order theory, the higher the level of company profit, the more funds available for used, so that corporations will tend to utilize their internal funds which come from profit compared to third party funds (debt), in line with that Nabela (2012) and Yaniate and Niken (2012) also put forward the same thing, that profitability has a negative effect on the Company's debt policy. Companies with high profitability will tend to use internal funds from retained earnings so that the company will not need funds originating from debt.

\section{Managerial Ownership}

Conflicts of interest between shareholders and managers are things that may occur in the implementation of company activities. Shareholders have the hope that managers will carry out and make financial decisions to increase the value of the company and the welfare of shareholders, but the financial decisions taken by managers sometimes conflict with shareholders (Hardiningsih and Oktaviani, 2012). Managers have more complete information about the condition of the company than shareholders.

Jensen and Meckling (1976) stated that large shareholders are more motivated and have more power to ensure the maximization of shareholder value by aligning the interests of shareholders with those of managers so that it will reduce agency costs. Managers will make fewer decisions that will have a negative impact on firm value because their share of costs increases with their share of capital in the company. Managerial ownership is also a way to reduce agency cost (Hardiningsih and Oktaviani, 2012) by inviting managers to become owners of company capital, so that financial decisions taken by managers who are also shareholders will also affect managers. Capital ownership by management will create a separate oversight of the policies to be taken by the company, including policies on the use of debt. Managers who are also shareholders will be more careful in making financial decisions because the risk of these decisions affects the capital they have deposited in the company. This is in line with the research results of Wahidahwati (2002), Indahningrum and Handayani (2009), Faisal (2004), Kurniati (2007) finding the conclusion that managerial ownership has a negative effect on the debt ratio. Meanwhile, Makaryanawati and Mamdy (2009) argue that there is no significant influence on managerial ownership and dividend policy on corporate debt policy.

Debt can be an alternative to reduce agency costs, as Mayangsari (2000) argues in Indahningrum and Handayani (2009). Whereas there are several alternatives that can be done to reduce agency costs, namely firstly by increasing the company's share ownership by management, secondly through the supervisory mechanism in the company, thirdly increasing the divident payout ratio, and fourthly by increasing debt financing. 


\section{Company Scale and Capacity}

Several studies have found that fixed assets have an influence on corporate debt. Previous studies conducted by previous researchers, such as Ferri and Jones (1979), Marsh (1982), Long and Malitz (1985), Friend and Lang (1988), and Jensen et al. (1992) also found that fixed assets have an effect on corporate debt. This finding is in accordance with the collateral hypothesis which argues that fixed assets can function as a bailout which indicates that a company has sufficient resources to fulfill its obligations, including liabilities in the form of debt (Mazur, 2007), Ramlall (2009) and Margareta and Ramadhan (2010). ) found that asset structure and firm size have a negative relationship with debt ratio which may be the result of low asymmetric information problems in large companies with large fixed assets. However, Wahidahwati (2002) found that the asset structure has a positive influence on debt policy, because the higher the proportion of in-place assets in the composition of the company's total assets, the higher the use of debt to the company concerned (Hardjopranoto 2006). This argument is also supported by Skinner (1993). The same conclusion is expressed by Masdupi (2005), Mas'ud (2008), Yeniatie and Destriana (2010).

Large companies can more easily access the capital market. Because of this convenience, it means that the company has the flexibility and ability to obtain funds (Wahidahwati 2002). This means that companies can easily get funds through stocks and debt. Large companies will find it easier to get debt because large companies usually have more assets in accordance with the collateral hypothesis. The results of Wahidahwati's (2002) study found that company size has an influence on debt ratio, which is consistent with the theory and previous research conducted by Homafiar et al. (1994) and Moh'd et al. (1998), in this case, companies tend to increase their debt because they are getting bigger and large companies have easy access to the capital market and also have the flexibility and ability to get sources of funds.

In a business context, as the research results of previous researchers (Hardiningsih and Oktaviani, 2012; Wahidahwati, 2002; Indahningrum and Handayani, 2009; Faisal, 2004; Kurniati, 2007; Nabela, 2012; Yaniate and Niken, 2012; Ismiyanti and Hanafi, 2003; Hardjopranoto, 2006; Skinner, 1993; Masdupi, 2005; Mas'ud, 2008; Yeniatie and Destriana, 2010). The debt function can be grouped into two main functions, namely; leverage (lever) which can be used by the principal to increase the company's profitability and control function. Debt serves as a corporate performance leverage as explained by Myers (1984), Ismiyanti and Hanafi (2003) and Indahningrum and Handayani (2009) that companies that experience a decrease in the level of profitability tend to use third party funds (debt) to respur their operations. This leverage can be divided into two, namely as financing for operations because the funds from profits are not sufficient to cover all operational costs or to increase production capacity through the purchase of fixed assets as stated by Wahidahwati (2002), Skinner (1993) and Masdupi (2005). With the increase in asset value and production capacity, the company value will also increase.

In addition to financial functions related to increasing profitability and production capacity, debt policy is also influenced by the control objectives of the principal. This is because the cost of capital that must be spent on agency costs in an agency relationship is considered more efficient for the principal and with an interest-based financing policy it is also easier to control the opportunistic behavior of managers compared to financing based on the addition of venture capital (shares).

\section{B. Debt in Islamic View}

Qardh means loans or debts. Etymologically, qardh means 'cutting) (1 Isnawati Rais and Hasanudin, Fiqh Muamalah and Its Application to Islamic Financial Institutions, (Jakarta: UIN Syarif Hidayatullah Research Institute, 2011) Cet. 1, p. 149. Named because of the money taken by the lender, cutting off part of his assets (Sabiq, 2008). The assets paid to the muqtarid (who are invited to the qardh contract) are called qarad, because they are a cut from the property of the muqrid (owner of the goods) (Lathif, 2005). Qiradh is a noun (masdar the word qiradh has the same language meaning as qardh. Qiradh also means the good and / or badness that we lend (Azhim, 2011). Al-Qardh is a loan given to muqtaridh who need funds and / or money (Ali, 2005).

The definition of al-qardh according to terminology, among others, was stated by Hanafiyah scholars. According to him qardh is "something that is given from the mithil (which has a parable) to meet his needs." Meanwhile, the definition of qardh according to the Malikiyah ulama is "a transfer of property to another person that is not accompanied by iwadh (reward) or additional in return." Meanwhile, according to the scholars of Syafi'iyah, "qardh has the same meaning as the term as-Salaf, namely the contract of ownership of something to be returned with the same or equivalent".

From this definition it appears that actually qardh is one type of approach to taqarrub to Allah and is a type of muamalah which is ta'awun (help) to other parties to meet their needs, because muqtaridh (debtor / debtor) is not obliged to give iwadh (additional) in return of the borrowed property to the muqridh (who provided the loan / creditor).

The teachings of the Islamic religion allow debt because debt is part of helping fellow humans (hablun minan naas) as in several letters and verses in the following Qur'an: 
"And please help you in goodness and piety, and do not help you in doing evil and damage." Al Maidah (5): 2

"If you lend to Allah a good loan, Allah will multiply the return to you and forgive you. And Allah is the most rewarding, the most Compassionate. " At Taghabun (64): 17

"Whoever wants to give a loan to Allah, a good loan (spend his wealth in the way of Allah), then Allah will multiply the payment to him by a large number. And Allah constricts and enlarges (sustenance) and it is to Him that you are returned. " Al Baqarah (2): 245

"Whoever wants to lend to Allah a good loan, Allah will multiply the loan (reward) for him, and he will get a great reward." Al Hadid (57): 11

"Surely those who give alms both men and women and lend to Allah a good loan, will undoubtedly be multiplied (the payment) to them, and for them the reward is many." Al Hadid (57): 18

"And indeed, Allah has taken the covenant (of) the children of Israel and We have raised 12 leaders among them and Allah says:" Verily I am with you, verily if you establish prayers and pay zakat and believe in My messengers and you help. them and you lend to Allah a good loan indeed I will wash away your sins. And indeed, I will enter into heaven that flows in the rivers. So, whoever disbelieves among you after that, verily, he has strayed from the straight path. " Al Maidah (5): 12

"So read what is easy (for you) from the Koran and establish prayers, pay zakat and give loans to Allah a good loan. And whatever good you do for yourself you will undoubtedly get (in return) with Allah as the best and the greatest reward. " Al Muzammil (73): 20

Prophet Muhammad SAW started his trade by owing a debt to a rich merchant who later became his wife, Khadijah al Kubro. He brought merchandise belonging to Khadija with his uncle Abu Talib to be traded in the city of Taif and other cities. The process of "bringing" merchandise was of course recorded both by the Prophet Muhammad SAW as the merchant of the merchandise and by Khadijah as the owner of the merchandise (Cahyadi, 2014).

Credit and Capital Transactions in Islam

If debt is a social contract, therefore it is not permissible to take profit, because every profit on debt is usury and riba is haram (Dzajuli, 2007) then how can the concept of financing / capital in Islam be implemented? As debt is used as an alternative capital / financing in mainstream business.

"Allah makes buying and selling legal and forbids usury." This is a piece of the translation of surah al-baqarah verse 275. Rasulullah salallahu alaihi wassalam said, which means "Three things that contain blessings are deferred buying and selling, performing qiradh (giving capital to others), and mixing wheat clearly for the family, not for sale. " (Narrated by Ibn Majah from Shuhaib). An alternative financing / capital that can be chosen by a company or individual in an Islamic context in order to avoid usury is financing obtained through sale and purchase or investment contracts (profit-loss sharing).

Islam separates between social transactions (taqarrub) which are non-profit and business transactions (ijarah) which are intended for profit. Debt in an Islamic perspective is a social contract with which it is haraam to seek profit by giving interest, a different perspective in mainstream business which assumes that interest is compensation for the use of assets through debt. A person has the right to receive benefits because he is willing to accept the risk of loss, as the Prophet salallahu alaihi wassalam said, which means "There must be no profit without taking the risk of loss." Therefore, profit transfers can only be received through business activities, not just money transfers.

\section{Buying and selling credit}

Islam allows those who buy goods, then sell them, either in cash or credit. Exceeding the price due to marking of payments is allowed. From Abdullah bin Amr bin al-'As Radhiallahu 'anhu and from his father said: Rasulullah sallallahu' alaihi wa sallam told me to owe a camel to be paid two camels of zakat. Narrated from Aisyah radhiyallahu 'anha, he has said: "The Messenger of Allah -peace and prayer of Allah be upon him- bought food from a Jew by deferring the payment, then he handed over the armor as a mortgage". Responding to the above hadith, the reasons put forward by al-Syantiqi are permissible

\section{Salam}

As-salam contract is a term in Arabic literacy which etymologically means to give, and leave and give priority. This means accelerating (transferring) capital or putting it first in a simple manner. In terms, as-salam is called selling an item whose delivery is postponed, or 
selling goods with clear characteristics with an early payment of capital, while the goods are delivered in a transaction under an order form known as as-salam.

The scholars of Syafi'iyah and Hanabilah define as-salam as a contract that is agreed upon in a certain way and pays first, while the goods are handed over at a later date. Imam Maliki defines as-salam as buying and selling whose capital is paid first, while the goods are delivered according to the agreed time (Djamil, 2013). The above jurisprudence experts differ in defining the as-salam transaction. This difference is based on the different requirements put forward by each of them regarding the legal basis of as-salam as stated in QS al-Baqarah, (2): 282, namely: If you are not in cash for the specified time, write it down. In relation to the above verse, Ibn Abbas explains the relevance of the verse to the as-salam transaction as he said, "I testify that as-salam which is guaranteed for a certain period of time has been allowed by Allah in His Book and permitted by Him". Ibn Abbas also reported that Rasulullah SAW came to Medina where the people performed as-salam to fruits for a period of one, two, three years, then he said: When Rasulullah SAW came to Medina, while the people of Medina owed dates for one year, two years and three years. Then Rasulullah SAW said that whoever owes the dates, he should pay it in a known amount, and a known scale and a known tempo (HR: Muslim).

The practice of plural salam is carried out in Islamic banking, salam is a sale and purchase contract like murabaha. The fundamental difference lies only in the payment and delivery of the object being traded. In the salam contract, the buyer is obliged to submit an advance payment for the object purchased, then the goods are handed over within a certain period of time. Salam can be applied as part of the financing that can be provided by a bank (individual / company) to a debtor who needs capital to run his business, while the bank (a company or individual acting as a principal) can get the proceeds from the customer's business and sell it to those concerned. This is better known as the parallel greeting. In the application of the salam contract, the bank acts as the buyer, while the customer acts as the seller. When the goods have been delivered to the bank, the bank will sell them to the customer's partner or to the customer themselves in cash or installments. The purchase price of a bank is the cost of goods plus profits (Muhammad, 2005).

\section{Mudaraba}

Mudaraba is a contract between two parties in which one party is called rab al-mal (investor) entrusting money to a second party, which is called mudharib, for the purpose of running a trading business (Saeed, 2004: 77). In terms, the scholars interpret mudaraba with different editors, but the substance is the same, namely a partnership agreement or cooperation between the owner of the capital (shahibul mal) and the manager of the capital (mudharib) with a mutually agreed profit sharing, while the financial loss is borne by the owner of the capital. The capital manager does not bear the financial risk because he has already borne other losses, namely in the form of labor and time (non-financial), unless the loss occurs due to fraud by the manager (al-Zuhaily, tt .: 836).

The principle of profit sharing in mudaraba bases the management of its business on the main philosophy of partnership and togetherness (sharing), in which there are elements of trust (trust), honesty and agreement. The Islamic emphasis on cooperation as a major concept in economic life has led to the belief that profit sharing and participation are basic alternatives to the Islamic financial system and other investments within the Islamic framework (Sa'diyah and Arifin, 2013). In addition, mudaraba contains the prudential principle, which is a principle that confirms that business activities carried out by the mudarib, as well as the transfer of capital by shahib al-mal must be done very carefully, and follow all binding provisions. the mudaraba agreement.

Through mudharabah, liquidity transfers can be bridged through a work project with one corporation as an investor while another corporation acts as a business actor or manager. In an Islamic perspective, any money involved in a business activity must be accompanied by goods or services that follow it, it is not permitted in the view of Islam to make money like debt in conventional business, "From the friend of Ibn Umar radhiallahu 'anhu, that the Prophet sallallaahu' alaihi wa sallam prohibits the sale and purchase of accounts receivable with accounts receivable. " (The history of Ad Daraquthny, Al Hakim and Al Baihaqy and this hadith is weakened by many scholars' including Imam As Shafi'i, Ahmad, and approved by Al Albany) (Qusthoniah, 2016).

\section{CONCLUSION}

1. In a business perspective, there is a dualistic perspective on debt. First, debt as leverage means that debt functions as a performance lever, namely the company's overall performance due to a lack of liquidity caused by low profit levels. Second, debt as a controlling tool for principals to agents, because bonus plans based on share / preferred capital are considered unable to trigger management (agent) performance while the principal's budget is too high, besides debt-based financing is considered more efficient, because interest costs can be used as a deduction for corporate tax.

2. Transfer of money (debt) in an Islamic perspective is considered a social activity by which a person who gives money is not allowed to take advantage, because every profit from debt is usury and riba is haram. Commercial liquidity transfers in Islam should not be just money alone, but must be accompanied by goods or services that are traded, because money is not a commodity so it is not allowed to exchange money for money accompanied by profit.

3. In an Islamic perspective, efficiency or managerial issues are not the main things that make a Muslim decide to choose interestbased financing. Halal or illegal transactions are the main reference for whether a financing model will be chosen, ribawi debt 
is not the main priority as a financing option. This is because Islam has provided some infrastructure in project financing or alternatives to leverage corporate liquidity alternatives, namely; Salam contract, murabahah contract, and mudharabah contract.

\section{REFERENCES}

[1] Alquran

[2] Abdul „Azhim Jalal Abu Zaid, Fiqh Riba, (Jakarta: Senayan Publishing), 2011, hlm. 323

[3] Ali, Zainuddin. 2008, Hukum Gadai Syariah, (Jakarta: Sinar Grafika, 2008).

[4] Atmaja, Lukas Setia, 2008, Teori dan Praktek Manajemen Keuangan, Yogyakarta, Penerbit ANDI.

[5] Basu, A.,Lal, R.,Srinivasan, V., and Staelin, R. 1985.Sales-force compensation plans : An agency theoretic perspective. Marketing science. Vo.4. No.2 Pp.267-291.

[6] Bernard, S Black, Hasung Jang, Woochan Kim, Kyung Suh Park. 2003. Does Corporate Governance Affects Firm Value: Evidence From Korea, Social Science Research Network, Science Research Network electronic library at: http://ssrn.com/abstract=844744

[7] Brigham, E.F. and L.C. Gapenski. 2006. Intermediate Financial Management. 7th edition. SeaHarbor Drive: The Dryden Press.

[8] Brigham, Eugene F. dan Joel F. Houston. 2011. Dasar-Dasar Manajemen Keuangan. Edisi Sebelas. Jakarta: Salemba Empat.

[9] Cahyadi, Ady. 2014. Mengelola Hutang Dalam Perspektif Islam. Jurnal Manajemen dan Bisnis.Vol. 4. No.1. April 2014.

[10] Demski, J.,Feltham, G. 1978. Economic incentives in budgetary control systems. Accounting Review.Vol.53. No.2. Pp.336-359.

[11] Djamil, Fathurrahman 2013. Penerapan Hukum Perjanjian dalam Transaksi di Lembaga Keuangan Syariah (Jakarta: Sinar Grafika, 2013 ), h. 132 Ahmad Mudzab Mahali. Ahmad Rodli Hasbullah, Hadist-hadist

[12] Eisenhardt, K. 1985. Control : Organizational and economic approaches. Management. Science. Vol.31. No.1. Pp.134-149.

[13] Eisenhardt, K. 1988. Agency and institutional explanations of compensation in retail sales. Academy of management journal. Vol.88. No.3. Pp.288-307.

[14] Fama, E.F. 1978. The Effect of a Firm's Investment and Financing Decision on the Welfare of its Security Holders. American Economic Review 68: June 272-284.

[15] Hardiningsih, Pancawati. Oktaviani, Rachmawati. Determinan Kebijakan Hutang (Dalam Agency Theory Dan Pecking Order Theory). Dinamika Akuntansi, Keuangan dan Perbankan, Mei 2012, Hal: $11-24$. ISSN :1979-4878

[16] Hadist

[17] Hasibuan, Zainal. 2007. “Metodologi Penelitian Pada Bidang Ilmu Komputer dan Teknologi Informasi”. Fikom UI, Jakarta.

[18] Indahningrum, R. P. dan R. Handayani. 2009. Pengaruh Kepemilikan Manajerial, Kepemilikan Institusional, Dividen, Pertumbuhan Perusahaan, Free Cash Flow, Dan Profitabilitas Terhadap Kebijakan Hutang Perusahaan. Jurnal Bisnis dan Akuntansi, Vol. 11, No. 3, hlm. 189-207.

[19] Ismiyanti, F. dan M. M. Hanafi. 2003. Kepemilikan Managerial, Kepemilikan Institusional, Risiko, Kebijakan Hutang, dan Kebijakan Deviden: Analisis Persamaan Simultan. Simposium Jurnal Akuntansi, Vol. 6, No. 7, hlm 260-277. Jensen, M. C and Meckling, W.H. 1976. Theory of the Firm : Managerial Behavior, Agency Costs and Ownership Structure . Journal of Financial Economics, Oktober, 1976, V. 3, No.4, $\quad$ pp. 305-360. Avalaible from http://papers.ssrn.com.

[20] Jensen M, and Meckling, W. 1976. "Theory of Firm: Managerial Behaviour Agency Cost and Ownership Structure”. Journal Of Finance and Economics, Vol. 3, No. 4, pp. 305-360.

[21] Lathif, Azharuddin. 2005. Fiqh Muamalat, (Jakarta: UIN Jakarta Press, 2005), Cet.1, hlm. 150.

[22] Karnadi, Steve H. 1993. Manajemen Pembelanjaan, Jakarta : Yayasan Promotio Humana.

[23] Kurniati, Wahyuning. 2007. "Pengaruh Struktur kepemilikan Terhadap Kebijakan Hutang Perusahaan”. Tesis. Universitas Diponegoro. Semarang.

[24] Masdupi, Erni. 2005. Analisis Dampak Struktur Kepemilikan pada Kebijakan Hutang dalam Mengontrol Konflik Keagenan, Jurnal ekonomi dan Bisnis Indonesia, Vol 20, No. 1, Januari, Hlm 57-69.

[25] Mas'ud, M, (2008), Analisis Faktor-Faktor yang Mempengaruhi Struktur Modal dan Hubungannya Terhadap Nilai Perusahaan, Manajemen dan Bisnis, Vol.7 No.1, Maret 2008.

[26] Mitnik, B. 1986. The theory of agency and organizational analysis. Unpublished working paper. University of Piyysburgh.

[27] Myers S.,(1984).The Capital Structure Puzzle. Journal of Finance. 39;575-592.

[28] Qusthoniah. 2016. Analisis Kritis Akad Salam dalam Perbankan Syariah. Jurnal Syari’ah Vol. V. No. 1. April.

[29] Sabiq, Sayyid. 2008. Fiqh Sunnah, (Jakarta: Pena Pundi Aksara, 2008), Jilid 4, hlm. 181

[30] Steven. Lina. 2011. Faktor-Faktor Yang Mempengaruhi Kebijakan Hutang Perusahaan. Jurnal Bisnis Dan Akuntansi. Vol. 13, No. 3, Desember 2011, Hlm. 163 181.

[31] Wahidahwati. 2002. Pengaruh Kepemilikan Manajerial dan Kepemilikan Institusional pada Kebijakan Hutang Perusahaan: Sebuah Perspektif Theory Agency. Jurnal Riset Akuntansi Indonesia, Vol. 5, No. 1, hlm. 1-16.

[32] Weston, Fred J dan Thomas E, Copeland. 2010. Manajemen Keuangan Jilid 2. Jakarta : Binarupa Aksara Publisher.

[33] White, H. 1985. Agency as control. In J. Pratt and R. Zeckhauser (Eds). Principals and agents : The structure of business (pp.187-214). Boston : Harvard Business School Press.

[34] Yeniatie dan N. Destriana. 2010. Faktor-Faktor yang Mempengaruhi Kebijakan Hutang pada Perusahaan Manufaktur yang Terdaftar di Bursa Efek Indonesia. Jurnal Bisnis dan Akuntansi, Vol. 12, No. 1, hlm. 1-16.

[35] Zuhaily, Wahbah, Al-. tt.. Al-Fqh al-Islami wa Adillatu, Juz IV. Beirut:Dar al-Fikr.

\section{AUTHORS}

First Author - Fianita Malati, Lecturer, fianita.malati@ stiemahardhika.ac.id

Second Author-M Andri Radiany, Lecturer, muhammad.andri@stiemahardhika.ac.id

This publication is licensed under Creative Commons Attribution CC BY.

http://dx.doi.org/10.29322/IJSRP.11.10.2021.p11805

WWW.ijsrp.org 
Third Author - Wulandari Harjanti, Lecturer, dra.wulandariong@gmail.com

Fourth Author - Ali Farhan, Lecturer, alifarhanfarhan@yahoo.com

Fifth Author - Etin Puspitasari, etin.puspitasari@stiemahardhika.ac.id

Correspondence Author - Fianita Malati, fianita.malati@stiemahardhika.ac.id 